Brazilian Journal

of Chemical

Engineering

\title{
CARBON DIOXIDE BIOFIXATION BY Chlorella sp. IN A BUBBLE COLUMN REACTOR AT DIFFERENT FLOW RATES AND $\mathrm{CO}_{2}$ CONCENTRATIONS
}

\author{
Reza Pourjamshidian ${ }^{1}$, Hossein Abolghasemi ${ }^{1}$, Mohammad Esmaili ${ }^{1}$, \\ Hossein D. Amrei ${ }^{2 *}$, Mehran Parsa ${ }^{1}$ and Shima Rezaei ${ }^{3}$ \\ ${ }^{1}$ University of Tehran, College of Engineering, School of Chemical Engineering, Tehran, Iran. \\ ${ }^{2}$ University of Bojnord, Faculty of Engineering, Department of Chemical Engineering, Bojnord, Iran. \\ E-mail: h.delavari@ub.ac.ir - ORCID: 0000-0002-8928-8332 \\ ${ }^{3}$ University of Tehran, Graduate Faculty of Environment, Tehran, Iran.
}

(Submitted: April 12, 2018 ; Revised: September 29, 2018 ; Accepted: November 20, 2018)

\begin{abstract}
CO}_{2}$ biofixation of the microalgae Chlorella sp. for different $\mathrm{CO}_{2}$ concentrations and gas flow rates in a bubble column reactor has been investigated in this study. Microalgae were cultivated under different $\mathrm{CO}_{2}$ concentrations (at $1.75 \%$ and $9.45 \% \mathrm{v} / \mathrm{v}$ ) and gas flow rates (at 30,50 and $70 \mathrm{ml} / \mathrm{min}$ ). The maximum specific growth rate of Chlorella sp. was obtained for the $\mathrm{CO}_{2}$ concentration of $1.75 \%$ and the gas flow rate of $50 \mathrm{~mL} / \mathrm{min}$. The highest biomass productivity rate (at $0.17 \mathrm{~g} \mathrm{~L}^{-1}$ day $^{-1}$ ) was for a sample with $1.75 \% \mathrm{CO}_{2}$ at a flow rate of 70 $\mathrm{ml} / \mathrm{min}$. Moreover, the results have shown that the specific growth rate and $\mathrm{CO}_{2}$ biofixation have a direct relation with culturing of Chlorella sp. Also, limiting $\mathrm{CO}_{2}$ supplementation noticeably decreased biomass concentration. Therefore, the results have shown that a high flow rate and low concentration of $\mathrm{CO}_{2}$ might promote a decrease in $\mathrm{CO}_{2}$ fixation efficiency by Chlorella sp.

Keywords: $\mathrm{CO}_{2}$ biofixation; Greenhouse gas; Microalgae; Biomass production; $\mathrm{CO}_{2}$ concentration.
\end{abstract}

\section{INTRODUCTION}

Climate change is considered to be an important issue for the environment and ecosystem. This phenomenon becomes far worse when more carbon dioxide $\left(\mathrm{CO}_{2}\right)$ is emitted into the atmospheric air (Schneider, 1989; Yen et al., 2015). According to some research, more carbon dioxide will be produced due to growing manufacturing industry, forms of transport and human activity (Belbute and Pereira, 2015; Monastersky). Despite the fact that the utilization of fossil fuels (oil and coal) is the decisive factor in global warming and climate change, the widespread use of an alternative renewable source of energies can play an important role in reducing environmental pollution and preventing using non-renewable resources, which are quite limited in the world (Gharabaghi et al., 2015; Amin, 2009; McKendry, 2002; Sawayama et al., 1999).
Microalgae are known as the third generation of renewable biomass resources for biofuel and biobased chemical production (Lee and Lavoie, 2013). In addition, microalgae have been described as a biological technology for $\mathrm{CO}_{2}$ capture because of their high ability of photosynthesis (Amin, 2009; CuéllarFranca and Azapagic, 2015; Martínez et al., 2013). Microalgae are mostly cultivated under atmospheric air (containing $0.03 \%$ of $\mathrm{CO}_{2}$ ). They can also grow in high levels of $\mathrm{CO}_{2}$ such as Flue gas from power plants (containing $12 \%-15 \%$ of $\mathrm{CO}_{2}$ ). Several studies have investigated microalgae cultivation under $\mathrm{CO}_{2}^{-}$ supplementation (Thomas et al., 2016; Watanabe and Fujii, 2016). Utilization of $\mathrm{CO}_{2}$ for microalgae cultivation has some advantages such as low cost, direct $\mathrm{CO}_{2}$ capturing from exhaust gas and simplicity in operation. Some researches confirm that microalgae are capable of biofixating 10-50 times more carbon

\footnotetext{
* Corresponding author: Hossein D. Amrei - E-mail: h.delavari@ub.ac.ir
} 
dioxide than terrestrial plants ( $\mathrm{Li}$ et al., 2008; Rosenberg et al., 2011; Soares et al., 2013).

Additional $\mathrm{CO}_{2}$ is necessary for the cultivation of microalgae through the photosynthetic process. However, a high carbon dioxide level in the medium of culture will cause a drop in the $\mathrm{pH}$ value, which inhibits the microalgae growth. Furthermore, microalgae cultivation under limitation in carbon dioxide usually restricts growth (de Godos et al., 2014; Yen et al., 2015). There are some parameters for optimization of $\mathrm{CO}_{2}$ biofixation depending on the species of microalgae, such as the nutrient availability, light intensity, temperature, $\mathrm{pH}$, sufficiently high surface area to volume ratio (height to diameter ratio), and countercurrent flow of gas and liquid at optimal flow rates (Cheng et al., 2013; Di Iaconi et al., 2006; JacobLopes et al., 2008; Janssen et al., 2003; Mohsenpour and Willoughby, 2016). Among microalgae species, Chlorella species are considered as a suitable choice for carbon dioxide fixation. In addition, Chlorella sp. have been highlighted because of their outstanding ability for converting high levels of $\mathrm{CO}_{2}$ in the input air of a photobioreactor into biomass (Chiu et al., 2008; Maeda et al., 1995).

In order to obtain the best operational condition for $\mathrm{CO}_{2}$ removal, the cultivation of Chlorella sp. was investigated under different $\mathrm{CO}_{2}$ concentrations and gas flow rates. Accumulation of fixed $\mathrm{CO}_{2}$ and daily $\mathrm{CO}_{2}$ fixation rate were also obtained for different conditions.

\section{MATERIALS AND METHODS}

\section{Microalgae and culture medium}

A culture of Chlorella sp. (PTCC 6010, Persian Type Culture Collection) was obtained from the Iranian Research Organization for Science and Technology (IROST) (Tehran, Iran). The cells of Chlorella sp. were cultured in Rudic's Medium (Delavari Amrei et al., 2015) (per liter), including $33 \mathrm{~g}$ Sea salt, $20 \mathrm{mg} \mathrm{NaCl}$, $10 \mathrm{mg} \mathrm{MgSO}{ }_{4} .7 \mathrm{H}_{2} \mathrm{O}, 47 \mathrm{mg} \mathrm{CaCl}, 300 \mathrm{mg} \mathrm{NaNO}$, $20 \mathrm{mg} \mathrm{KH} \mathrm{PO}_{4}, 80 \mathrm{mg} \mathrm{K} \mathrm{HPO}_{4}, 0.1 \mathrm{mg} \mathrm{ZnSO} \mathrm{Z}_{4} .7 \mathrm{H}_{2} \mathrm{O}$, $7.5 \mathrm{mg} \mathrm{Na}$. EDTA, $17 \mathrm{mg} \mathrm{FeCl}{ }_{3} .6 \mathrm{H}_{2} \mathrm{O}, 0.3 \mathrm{H}_{3} \mathrm{BO}_{3}$, $0.3 \mathrm{mg}\left(\mathrm{NH}_{4}\right)_{6} \mathrm{Mo}_{7} \mathrm{O}_{24} \cdot 4 \mathrm{H}_{2} \mathrm{O}, 17 \mathrm{mg} \mathrm{FeCl} \cdot 6 \mathrm{H}_{2} \mathrm{O}, 0.2$ $\mathrm{mg} \mathrm{Co}\left(\mathrm{NO}_{3}\right)_{2} \cdot \mathrm{H}_{2} \mathrm{O}, 1.5 \mathrm{mg} \mathrm{MnSO}_{4} \cdot \mathrm{H}_{2} \mathrm{O}, 0.08 \mathrm{mg}$ $\mathrm{CuSO}_{4} .5 \mathrm{H}_{2} \mathrm{O}, 0.1 \mathrm{mg} \mathrm{ZnSO} \mathrm{Zn}_{4} .7 \mathrm{H}_{2} \mathrm{O}$.

\section{Experimental setup and cultivation conditions}

The microalgae were cultured in a cylindrical glass reactor (diameter $14 \mathrm{~cm}$, height $1 \mathrm{~m}$ ) with 10 $\mathrm{L}$ of working volume. Cultures were placed on a bench at $26 \pm 1{ }^{\circ} \mathrm{C}$ under cool-white fluorescent light (General Electric) for 16 days. Light intensity was approximately $87.75 \mu \mathrm{mol} \mathrm{m} \mathrm{m}^{-2} \mathrm{~s}^{-1}$ at the surface of the photobioreactor, measured with a Lux-meter (HTC, India; Model no. 102). The experimental set-up is presented in Fig. 1.

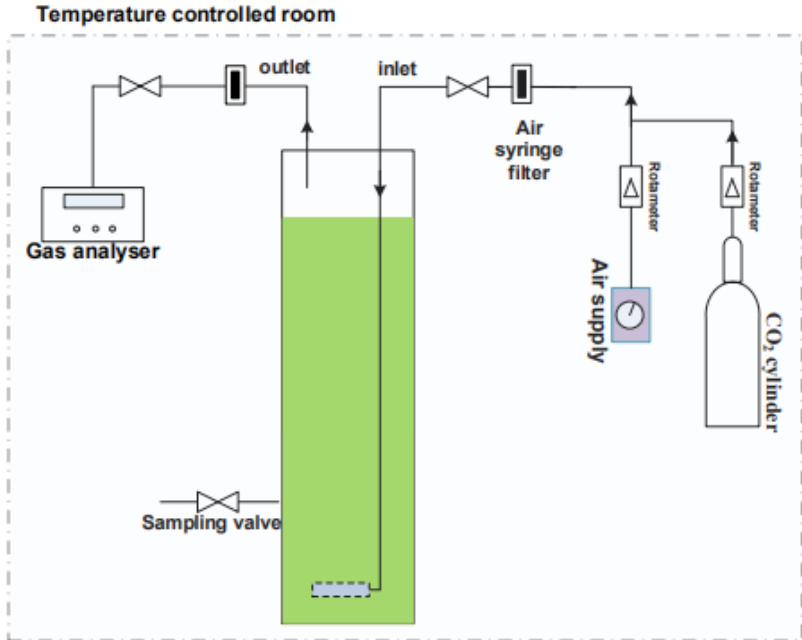

Figure 1. Experimental set-up.

Ambient air was mixed with $\mathrm{CO}_{2}$ to give optional concentrations by a gas mixer instrument. Aeration gas was filter sterilized and pumped into the microalgae culture medium. The $\mathrm{CO}_{2}$ and $\mathrm{O}_{2}$ concentrations of the gas in the input and output of the photobioreactor were measured using a STAR GAS global diagnostics system. A portable multiparameter ( $\mathrm{pH} / \mathrm{DO} / \mathrm{Temp} / \mathrm{EC})$ HANNA HI98194 instrument was used in each run of photobioreactor to monitor online and record dissolved oxygen (DO), temperature, and $\mathrm{pH}$. In each case, the probes were put in the photobioreactor for 2 minutes. All the experiments were repeated in triplicate, and the average values were represented.

In this study, four runs of experiments for microalgae growth under various $\mathrm{CO}_{2}$ concentration levels and gas flow rate were applied (Table 1).

Table 1. $\mathrm{CO}_{2}$ concentration and gas flow rate for different runs.

\begin{tabular}{ccc}
\hline Exp. No. & $\begin{array}{c}\mathbf{C O}_{2} \text { concentration } \\
(\mathbf{v} / \mathbf{v} \%)\end{array}$ & $\begin{array}{c}\text { Gas flow rate } \\
(\mathbf{m L} / \mathbf{m i n})\end{array}$ \\
\hline Run 1 & 9.45 & 50 \\
Run 2 & 1.75 & 50 \\
Run 3 & 1.75 & 30 \\
Run 4 & 1.75 & 70 \\
\hline
\end{tabular}

\section{Growth monitoring and assessed parameters}

The optical density of broth was measured by the absorbance at $560 \mathrm{~nm}$ in an Ultrospec 3300 pro UV/ Visible spectrophotometer (Amersham Biosciences, Cambridge, UK). The relationship between the biomass concentration $(\mathrm{X}, \mathrm{g} / \mathrm{L})$ or dry weight and optical density $\left(\mathrm{OD}_{560}\right)$ is obtained as follows (Delavari Amrei et al., 2014):

$$
\mathrm{X}=0.49 \times \mathrm{OD}_{560}
$$

Various concentrations of carbon dioxide were utilized for aeration of the culture medium inside the 
photobioreactors. Air containing $0.03 \% \mathrm{CO}_{2}, 1.75 \%$ and $9.45 \% \mathrm{CO}_{2}$ was used to evaluate the effect of improving $\mathrm{CO}_{2}$ fixation rates. The selected proportion of $\mathrm{CO}_{2}$ in these aeration conditions was based on the composition of $\mathrm{CO}_{2}$ in industrial flue gases.

Based on the mass balance of microalgae, the fixation rate of $\mathrm{CO}_{2}$ can be evaluated. The accumulation of fixed $\mathrm{CO}_{2}\left(\mathrm{FA}, \mathrm{g} \mathrm{CO}_{2}\right.$ ) was calculated based on Eq. 2 (Moraes et al., 2016):

$\mathrm{FA}=\left(\mathrm{X}_{\mathrm{t}}-\mathrm{X}_{0}\right) \times \mathrm{C}_{\mathrm{c}} \times \mathrm{V} \times\left(\frac{\mathrm{M}_{\mathrm{CO}_{2}}}{\mathrm{M}_{\mathrm{c}}}\right)$

where $X_{t}\left(g . L^{-1}\right)$ is the concentration of the biomass at time $t$ (days), $X_{0}\left(\mathrm{~g} . \mathrm{L}^{-1}\right)$ is the concentration of microalgae at time $\mathrm{t}_{0}, \mathrm{C}_{\mathrm{c}}\left(\mathrm{g}_{\mathrm{c}} / \mathrm{g}_{\text {sample }}\right)$ is the fraction of carbon determined in the biomass, $\mathrm{V}(\mathrm{L})$ is the volume of the photobioreactor, and $\mathrm{M}_{\mathrm{CO} 2}$ and $\mathrm{M}_{\mathrm{C}}\left(\mathrm{gmol}^{-1}\right)$ are the molar masses of carbon dioxide and carbon present in the microalgae biomasses, respectively. Carbon dioxide is the main source of the carbon content of the microalgae cell. A mole of $\mathrm{CO}_{2}$ has a mass of $44 \mathrm{~g}$ including $12 \mathrm{~g}$ of carbon. The daily $\mathrm{CO}_{2}$ fixation rate (FD, $\left.\mathrm{g}_{\mathrm{CO} 2 \mathrm{Bi} i \mathrm{Fixed}} / \mathrm{g}_{\mathrm{CO} 2 \text { InjectedDay }}\right)$ was achieved during the growth period according to Eq. 3:

$\mathrm{FD}=\frac{\left(\mathrm{FA}_{(\mathrm{t}+1)}-\mathrm{FA}_{(\mathrm{t})}\right)}{\mathrm{m}_{\mathrm{id}}}$

where $\mathrm{FA}_{(\mathrm{t}+1)}$ and $\mathrm{FA}_{(\mathrm{t})}$ are the $\mathrm{CO}_{2}$ accumulated at time $\mathrm{t}+1$ (day) and time $\mathrm{t}$ (day), respectively. Also, $\mathrm{m}_{\mathrm{id}}\left(\mathrm{g}_{\mathrm{CO} 2}\right)$ is the mass of daily injected of $\mathrm{CO}_{2}$. Therefore, the maximum daily $\mathrm{CO}_{2}$ fixation rate $\left(\mathrm{F}_{\mathrm{CO} 2}\right)$ was achieved at the maximal (FD) value during the growth period.

The specific growth rate $(\mu)$ is calculated according to the following equation. Substantially, the specific growth rate is the slope of the biomass productivity curve or, in other words, the daily rate of the biomass growth.

$\mu=\frac{\ln \left(\frac{C_{n}}{C_{n-1}}\right)}{t_{n}-t_{n-1}}$

where $\mathrm{C}_{\mathrm{n}}$ and $\mathrm{C}_{\mathrm{n}-1}$ are the biomass concentrations ( $\mathrm{g}$ $\mathrm{L}^{-1}$ ) on the days $\mathrm{t}_{\mathrm{n}}$ and $\mathrm{t}_{\mathrm{n}-1}$, respectively.

\section{RESULTS AND DISCUSSION}

Effect of different concentrations of $\mathrm{CO}_{2}$ on microalgae culture

Fig. 2 presents the growth curves obtained for Chlorella sp. grown in air streams containing the

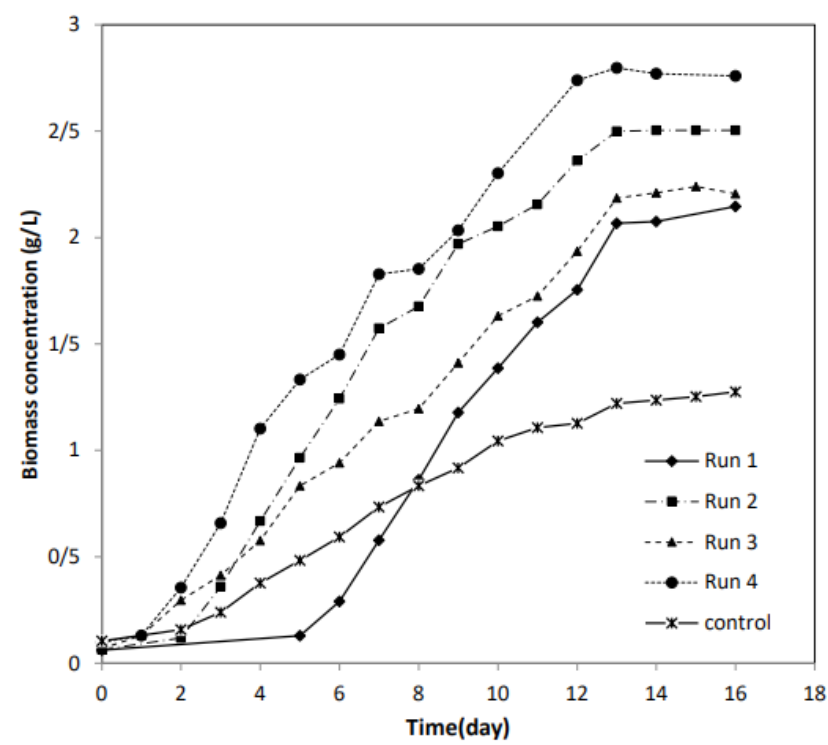

Figure 2. Time course for cell growth at different concentrations of $\mathrm{CO}_{2}$.

different $\mathrm{CO}_{2}$ concentrations and different flow rates that are presented in Table 1. Also, the $\mathrm{pH}$ variation of samples is shown in Fig. 3. The average range of $\mathrm{pH}$ is between 7 and 8 . In the first run of experiments, the culture of microalgae was aerated after four days with $9.75 \% \mathrm{CO}_{2}$ and a gas flow rate of $50 \mathrm{~mL} / \mathrm{min}$. The maximum growth of microalgae happened in the fifth and sixth days and the final dry cell concentrations were $2.15 \mathrm{~g} / \mathrm{L}$ after 16 days.

As shown in Figs. 4 and 5, the maximum level of $\mathrm{CO}_{2}$ removal occurred on the day that $\mu$ was the maximum for all of the experiments. In fact, for the first run $\mathrm{n}$ the 6 th day, the microalgae growth rate was the highest, at $0.811 /$ day, and more $\mathrm{CO}_{2}$ was consumed so that the maximum of daily $\mathrm{CO}_{2}$ biofixation rate was

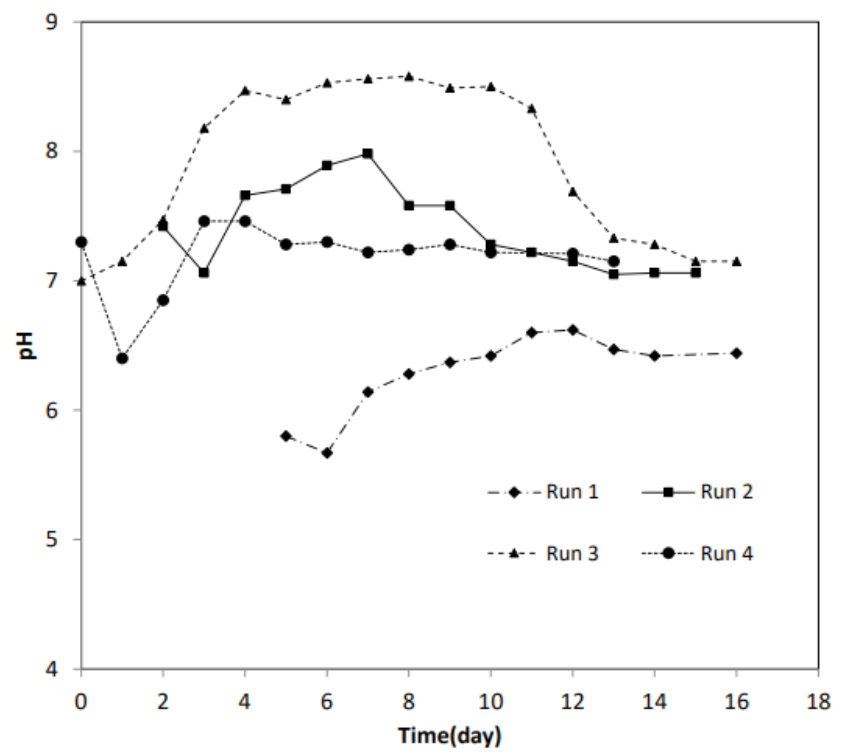

Figure 3. $\mathrm{pH}$ variations of the microalgae under different $\mathrm{CO}_{2}$ aeration levels. 


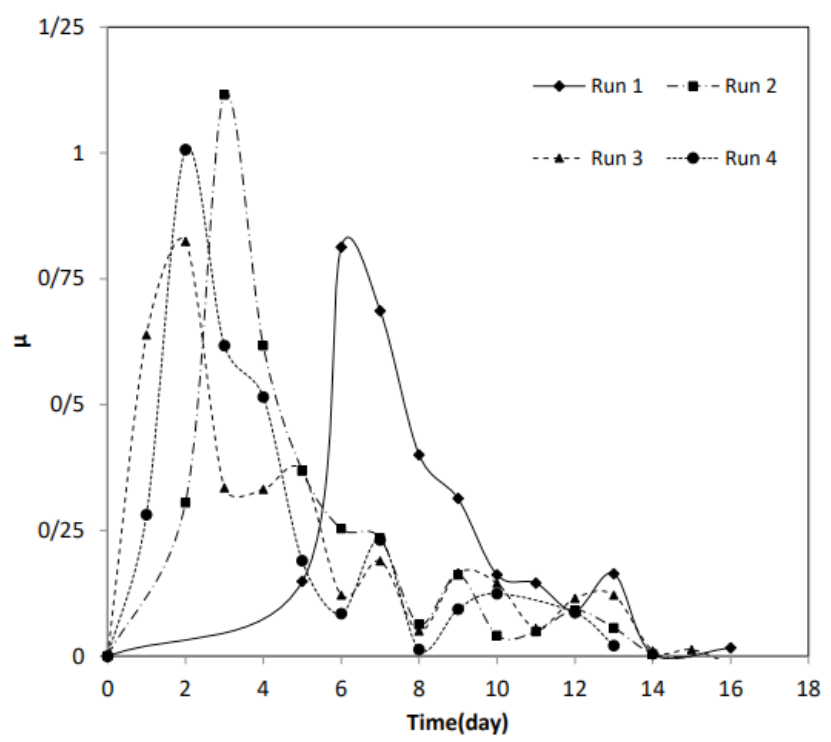

Figure 4. Specific growth rate variations of the microalgae under different $\mathrm{CO}_{2}$ aeration levels.

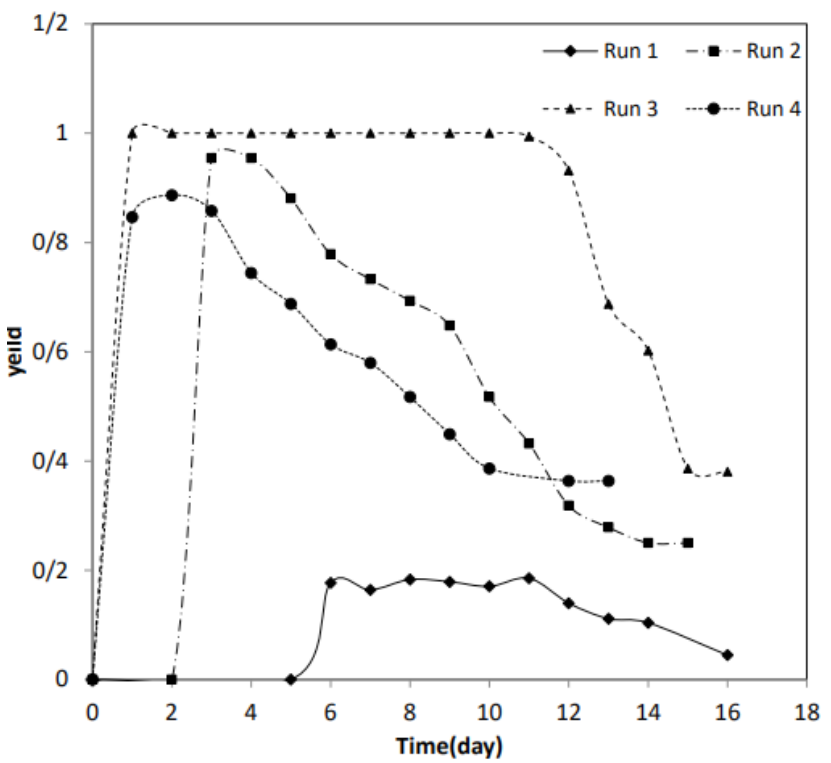

Figure 5. $\mathrm{CO}_{2}$ removal percent for different $\mathrm{CO}_{2}$ aeration levels.

about $17 \%$. Therefore, the $\mu$ value and the percentage of $\mathrm{CO}_{2}$ removal are closely linked. In the first run, there was a long lag phase due to high $\mathrm{CO}_{2}$ concentration (at $9.45 \%)$. Furthermore, the exponential phase, as well as the maximum level of $\mathrm{CO}_{2}$ removal, occurred on the sixth day. Also, in the first run, with increasing mass concentration in the photobioreactor and turbidity of the solution after the eleventh day, the percentage of $\mathrm{CO}_{2}$ in the output gas climbed by about $5.6 \%$ (from 7.7 to 8.13 ).

$\mathrm{CO}_{2}$ concentration has an impact on the metabolism of carbon and algae photochemical properties (Zhao and $\mathrm{Su}, 2014)$. Because carbon dioxide is the main source of carbon, a limited supply of carbon dioxide concentration will inhibit algae productivity. A high $\mathrm{CO}_{2}$ concentration could inhibit algae growth because of a decrease in $\mathrm{pH}$ to lower than 5.5 in the cultivation system.

In the second run of experiments, the solution of microalgae was aerated after two days with a $\mathrm{CO}_{2}$ concentration $1.75 \%$ and flow of $50 \mathrm{~mL} / \mathrm{min}$. Dry mass of algae in the second run reached its highest value at $2.5 \mathrm{~g} / \mathrm{L}$ on the $12^{\text {th }}$ day. The dry mass of microalgae increased in comparison with the first run due to lower $\mathrm{CO}_{2}$ concentration and a rise in the average $\mathrm{pH}$ from around 6.3 to 7.5 . On the third day, the $\mu$ value peaked at $1.1\left(\right.$ day $\left.^{-1}\right)$.

In the third run of experiments, for investigating the effect of low gas flow rate and limited $\mathrm{CO}_{2}$ access, the solution of microalgae was aerated with $1.75 \%$ $\mathrm{CO}_{2}$ and a low flow rate $30 \mathrm{~mL} / \mathrm{min}$. The dry mass concentration of algae fell to $2.25 \mathrm{~g} / \mathrm{L}$ on the $16^{\text {th }}$ day ( $10 \%$ decrease in comparison with the second run) due to low $\mathrm{CO}_{2}$ flow rate. The main cause is the lack of sufficient carbon dioxide that is considered as the main carbon source.

High mixing intensity could harm algae, while a sufficient mixing intensity is required for transferring of substances. In the fourth run of experiments, for the investigation of the effect of the high gas flow rate, the solution of microalgae was aerated with $1.75 \% \mathrm{CO}_{2}$ and a flow rate of $70 \mathrm{ml} / \mathrm{min}$.

As shown in Fig. 4, as in the second and third runs, in the fourth run, the $\mu$ value on the second day after aeration reached its highest value. Also, the maximum level of $\mathrm{CO}_{2}$ fixation yield on the second day for the second, third, and fourth runs happened at $100 \%$, $97 \%$, and $94 \%$, respectively. The plus point of this test was that the dry mass concentration value peaked at $2.8 \mathrm{~g} / \mathrm{L}$ in 13 days in comparison with the other runs due to proper mixing in the system and an adjusted $\mathrm{pH}$ value with the microalgae activity in the optimal condition.

The $\mathrm{pH}$ of the algae culture is related to the solubility and availability of carbon dioxide in the photobioreactor (Mohsenpour and Willoughby, 2016). Bicarbonate is the determining factor in the photosynthesis of microalgae. Variation of the $\mathrm{pH}$ results in changing proportions of carbon compounds (carbon dioxide, bicarbonate, and carbonate). Nevertheless, among these compounds, the consumption of carbonate in algae photosynthesis is still being investigated and discovered (Price et al., 2004). Therefore, the amounts of carbon dioxide and bicarbonate transporters may be the main contributing factor in determining the carbon transfer rate. It should also be noted that the carbon transfer rate may make changes in the ratios of assimilation of carbon and nitrogen and affect the cell composition (Hsueh et al., 2007). When the $\mathrm{pH}$ 
of the algae cultivation is between 6.8 and 8.4 , more than $50 \%$ of the inlet $\mathrm{CO}_{2}$ converts to bicarbonate and, at $\mathrm{pH} 8.4$, the carbon dioxide converts to bicarbonate completely. So, the optimal condition for algae growth will be achieved in the range of approximately $\mathrm{pH} 6.8$ to $\mathrm{pH}$ 8. Similarly, Hsueh et al. (2007) have shown that, whereas the maximum growth rate was achieved in approximately the above -mentioned range, this rate decreased at the higher $\mathrm{pH}$. Thus, it was logical that the maximum dry mass concentration was obtained in the fourth run and the photosynthesis increased in this run.

As shown in Fig. 3, in the first run, the $\mathrm{pH}$ value of the solution rose exponentially (until the eleventh day) from 5.8 to 6.62 and declined steadily to 6.4 with decreasing microorganism activity.

In the second and fourth runs, with $1.75 \% \mathrm{CO}_{2}$ concentration, the initial value near neutral $\mathrm{pH}$ remained steady at 7.5 and 7.3 for a gas flow rate of 50 and $70 \mathrm{ml} / \mathrm{min}$, respectively. There was a slight increase in the $\mathrm{pH}$ during the aeration flow of 50 and $70 \mathrm{~mL} / \mathrm{min}$; however, in the third run, there was an obvious increase in the $\mathrm{pH}$ and it remained steady at 8.5 because the amount of $\mathrm{CO}_{2}$ in the solution was lower. This may be attributed to the relation between $\mathrm{pH}$, biomass growth and photosynthetic demand. With increasing $\mathrm{CO}_{2}$ in the algal solution, the $\mathrm{pH}$ will decline. On the other hand, with rising $\mathrm{CO}_{2}$, photosynthesis and algae growth will rise and algae growth leads to an increase in the $\mathrm{pH}$. The same results have been achieved by several authors. According to de Morais and Costa (2007) and Grobbelaar (2004), the photosynthetic process of $\mathrm{CO}_{2}$ fixation, owing to the accumulation of $\mathrm{OH}^{-}$, leads to a moderate rise in $\mathrm{pH}$. On the other hand, the dissolution of $\mathrm{CO}_{2}$ in water brings about acidification because of the formation of carbonic acid. Moreover, Chinnasamy et al. (2009) also observed that the initial $\mathrm{pH}$ decreased with increasing $\mathrm{CO}_{2}$ concentration and consequently the $\mathrm{pH}$ increased with the growth of $C$. vulgaris.

As shown in Fig. 4, the specific growth rate of microalgae in the minimum of the concentration of $\mathrm{CO}_{2}$ (at $1.75 \%$ ) is more than at the maximum of the $\mathrm{CO}_{2}$ concentration (at 9.45\%). This is because of a plummet in the $\mathrm{pH}$ value with increasing $\mathrm{CO}_{2}$ concentration of the solution.

As shown in Fig. 2, the $\mathrm{CO}_{2}$ supplement has a positive effect on the growth rate and the mass production of the microalgae in comparison with the absence of $\mathrm{CO}_{2}$ gas aeration. As a result, without $\mathrm{CO}_{2}$ the growth curve was linear $\left(\mathrm{R}^{2}=0.9145\right)$, while it changed with $\mathrm{CO}_{2}$ aeration to an exponential shape. As shown in Figure 2, the maximum production of biomass was at $1.27 \mathrm{~g} / \mathrm{L}$ in ambient air, which was significantly lower than biomass in culture under $\mathrm{CO}_{2}$ supplementation.

\section{Carbon fixation}

The accumulation of fixed $\mathrm{CO}_{2}\left(\mathrm{FA}, \mathrm{g}_{\mathrm{CO} 2}\right)$ by Chlorella sp., calculated using Equation (2) for the experimental runs, is reported in Table 2. The highest figure for the accumulation of fixed $\mathrm{CO}_{2}$ of $49.5 \mathrm{~g}_{\mathrm{CO} 2}$ was seen at a $\mathrm{CO}_{2}$ air ratio of $1.75 \%$ and $70 \mathrm{ml} / \mathrm{min}$. With increasing flow at $1.75 \% \mathrm{CO} 2$ air ratio, the daily $\mathrm{CO}_{2}$ biofixation rate decreased due to the limited capacity of algae photosynthetic.

Also, as shown in Fig. 5, maximum daily $\mathrm{CO}_{2}$ biofixation happened in the third run (at $1.75 \% \mathrm{CO}_{2}$ air ratio and at $30 \mathrm{ml} / \mathrm{min}$ flow). In the third run, the $\mathrm{CO}_{2}$ content in the output gas was roughly zero. Therefore, the maximum figure for removed carbon dioxide and produced oxygen can be easily calculated per gram of algae. The $\mathrm{O}_{2}$ production and $\mathrm{CO}_{2}$ consumption by the system per gram of algae is $0.603 \mathrm{~g}_{\mathrm{O} 2} \mathrm{~g}^{-1} \mathrm{day}^{-1}$ and 0.624 $\mathrm{g}_{\mathrm{CO} 2} \mathrm{~g}^{-1}$ day $^{-1}$, respectively. Furthermore, on the second day, the $\mathrm{CO}_{2}$ biofixation rate and $\mu$ value peaked simultaneously, owing to the high algae absorption in the exponential growth. The $\mathrm{CO}_{2}$ biofixation rate also remained at $100 \%$ as the algae entirely consumed the inlet $\mathrm{CO}_{2}$ to fix it.

Table 2. Maximal biomass concentration (Xmax, $\left.\mathrm{g} \mathrm{L}^{-1}\right)$, maximal specific growth rate $\left(\mu_{\max }\right.$, day $\left.^{-1}\right)$, maximal daily $\mathrm{CO}_{2}$ biofixation rate $\left(\mathrm{F}_{\mathrm{CO} 2}, \% \mathrm{v} / \mathrm{v}\right)$ obtained for the runs of the experiment.

\begin{tabular}{cccccc}
\hline Exp. No. & $\begin{array}{c}\text { Xmax } \\
\left(\mathbf{g . L}^{-1}\right)\end{array}$ & $\begin{array}{c}\boldsymbol{\mu}_{\text {max }} \\
\left(\mathbf{d a y}^{-1}\right)\end{array}$ & $\begin{array}{c}\text { Biomass } \\
\text { Productivity } \\
\text { Rate } \\
\left(\mathbf{g ~ L}^{-1} \text { day }^{-1}\right)\end{array}$ & $\begin{array}{c}\mathbf{F}_{\mathbf{C O} 2} \\
(\mathbf{\%})\end{array}$ & $\begin{array}{c}\text { FA } \\
\left(\mathbf{g C O}_{2}\right)\end{array}$ \\
\hline Run 1 & 2.14 & 0.81 & 0.12 & 17.67 & 37.2 \\
Run 2 & 2.5 & 1.11 & 0.15 & 95.45 & 44.7 \\
Run 3 & 2.25 & 0.82 & 0.14 & 100 & 40.0 \\
Run 4 & 2.8 & 1.00 & 0.17 & 88.63 & 49.5 \\
\hline
\end{tabular}

\section{CONCLUSIONS}

This study reveals that culturing microalgae with different levels of $\mathrm{CO}_{2}$ concentrations can lead to various microalgae specific growth rates. So, $\mathrm{CO}_{2}$ biofixation is of major significance. The highest value of $\mu$ was found at $1.75 \% \mathrm{CO}_{2}$ and $50 \mathrm{~mL} / \mathrm{min}$ flow rate in $1.11 \mathrm{day}^{-1}$. This paper shows that the best biofixation of $\mathrm{CO}_{2}$ was 44.7 $\mathrm{g}_{\mathrm{CO} 2}$ after 16 days, which occurred in the region where $\mu$ was high and $\mathrm{CO}_{2}$ accumulation was the maximum. At $1.75 \% \mathrm{CO}_{2}$ air ratio and at $30 \mathrm{~mL} / \mathrm{min}$ flow, $100 \%$ $\mathrm{CO}_{2}$ biofixation occurred, but a significant and high efficiency of the growth rate was not observed due to the lack of carbon dioxide. As a result, the microalgae Chlorella sp. has a great potential for biofuel production and $\mathrm{CO}_{2}$ capturing so as to reduce the negative impacts of greenhouse gas and global warming. 


\section{REFERENCES}

Amin, S. Review on biofuel oil and gas production processes from microalgae. Energy Conversion and Management, 50, 1834-1840 (2009). https:// doi.org/10.1016/j.enconman.2009.03.001

Belbute, J.M., Pereira, A.M. An alternative reference scenario for global $\mathrm{CO} 2$ emissions from fuel consumption: An ARFIMA approach. Economics Letters, 136, 108-111 (2015). https://doi. org/10.1016/j.econlet.2015.09.001

Cheng, J., Huang, Y., Feng, J., Sun, J., Zhou, J., Cen, K., Improving $\mathrm{CO}_{2}$ fixation efficiency by optimizing Chlorella PY-ZU1 culture conditions in sequential bioreactors. Bioresource Technology, 144, 321-327 (2013). https://doi.org/10.1016/j. biortech.2013.06.122

Chinnasamy, S., Ramakrishnan, B., Bhatnagar, A., Das, K.C. Biomass Production Potential of a Wastewater Alga Chlorella vulgaris ARC 1 under Elevated Levels of $\mathrm{CO}_{2}$ and Temperature. International Journal of Molecular Sciences, 10, 518-532 (2009). https://doi.org/10.3390/ijms10020518

Chiu, S.Y., Kao, C.Y., Chen, C.H., Kuan, T.C., Ong, S.C., Lin, C.S. Reduction of $\mathrm{CO}_{2}$ by a high-density culture of Chlorella sp. in a semicontinuous photobioreactor. Bioresource Technology, 99, 3389-3396 (2008). https://doi.org/10.1016/j. biortech.2007.08.013

Cuéllar-Franca, R.M., Azapagic, A. Carbon capture, storage and utilization technologies: A critical analysis and comparison of their life cycle environmental impacts. Journal of $\mathrm{CO}_{2}$ Utilization, 9, 82-102 (2015). https://doi.org/10.1016/j. jcou.2014.12.001

De Godos, I., Mendoza, J.L., Acién, F.G., Molina, E., Banks, C.J., Heaven, S., Rogalla, F. Evaluation of carbon dioxide mass transfer in raceway reactors for microalgae culture using flue gases. Bioresource Technology, 153, 307-314 (2014). https://doi. org/10.1016/j.biortech.2013.11.087

De Morais, M.G., Costa, J.A.V. Biofixation of carbon dioxide by Spirulina sp. and Scenedesmus obliquus cultivated in a three-stage serial tubular photobioreactor. Journal of Biotechnology, 129, 439-445 (2007). https://doi.org/10.1016/j. jbiotec.2007.01.009

Delavari Amrei, H., Nasernejad, B., Ranjbar, R., Rastegar, S. An integrated wavelength-shifting strategy for enhancement of microalgal growth rate in PMMA- and polycarbonate-based photobioreactors. European Journal of Phycology, 49, 324-331 (2014). https://doi.org/10.1080/09670 262.2014.919030

Delavari Amrei, H., Ranjbar, R., Rastegar, S., Nasernejad, B., Nejadebrahim, A. Using fluorescent material for enhancing microalgae growth rate in photobioreactors. Journal of Applied Phycology, 27, 67-74 (2015). https://doi.org/10.1007/s10811014-0305-7

Di Iaconi, C., Ramadori, R., Lopez, A. Combined biological and chemical degradation for treating a mature municipal landfill leachate. Biochemical Engineering Journal, 31, 118-124 (2006). https:// doi.org/10.1016/j.bej.2006.06.002

Grobbelaar, J.U., Algal Nutrition - Mineral Nutrition. In Handbook of Microalgal Culture, A. Richmond (Ed.), Blackwell Publishing Ltd., (2004).

Gharabaghi, M., Amrei, H.D., Zenooz, A.M., Guzullo, J.S., Ashtiani, F.Z. Biofuels: bioethanol, biodiesel, biogas, biohydrogen from plants and microalgae. In $\mathrm{CO}_{2}$ Sequestration, Biofuels and Depollution (pp. 233-274). Springer, Cham. (2015). https://doi. org/10.1007/978-3-319-11906-9 6

Jacob-Lopes, E., Cacia Ferreira Lacerda, L.M., Franco, T.T. Biomass production and carbon dioxide fixation by Aphanothece microscopic Nägeli in a bubble column photobioreactor. Biochemical Engineering Journal, 40, 27-34 (2008). https://doi. org/10.1016/j.bej.2007.11.013

Janssen, M., Tramper, J., Mur, L.R., Wijffels, R.H. Enclosed outdoor photobioreactors: Light regime, photosynthetic efficiency, scale-up, and future prospects. Biotechnology and Bioengineering, 81, 193-210 (2003). https://doi.org/10.1002/bit.10468

Lee, R.A., Lavoie, J.M. From first- to third-generation biofuels: challenges of producing a commodity from a biomass of increasing complexity. Animal Frontiers, 3, 6-11 (2013). https://doi.org/10.2527/ af.2013-0010

Li, Y., Horsman, M., Wu, N., Lan, C.Q., Dubois-Calero, N., Biofuels from Microalgae. Biotechnology Progress, 24, 815-820 (2008). https://doi. org/10.1021/bp070371k

Maeda, K., Owada, M., Kimura, N., Omata, K., Karube, I. $\mathrm{CO}_{2}$ fixation from the flue gas on coalfired thermal power plant by microalgae. Energy Conversion and Management, 36, 717-720 (1995). https://doi.org/10.1016/0196-8904(95)00105-M

Martínez, L., Otero, M., Morán, A., García, A.I. Selection of native freshwater microalgae and cyanobacteria for $\mathrm{CO}_{2}$ biofixation. Environmental Technology, 34, 3137-3143 (2013). https://doi.org $/ 10.1080 / 09593330.2013 .808238$

McKendry, P. Energy production from biomass (part 2): conversion technologies. Bioresource Technology, 83, 47-54 (2002). https://doi.org/10.1016/S09608524(01)00119-5

Mohsenpour, S.F., Willoughby, N., Effect of $\mathrm{CO}_{2}$ aeration on the cultivation of microalgae in luminescent photobioreactors. Biomass and Bioenergy, 85, 168-177 (2016). https://doi. org/10.1016/j.biombioe.2015.12.002 
Monastersky, R. Global carbon dioxide levels near a worrisome milestone. Nature, 497, 13-14 (2013). https://doi.org/doi:10.1038/497013a

Moraes, L., Rosa, G.M. de, Cardias, B.B., Santos, L.O. dos, Costa, J.A.V. Microalgal biotechnology for greenhouse gas control: Carbon dioxide fixation by Spirulina sp. at different diffusers. Ecological Engineering, 91, 426-431 (2016). https://doi. org/10.1016/j.ecoleng.2016.02.035

Price, G.D., Woodger, F.J., Badger, M.R., Howitt, S.M., Tucker, L. Identification of a SulP-type bicarbonate transporter in marine cyanobacteria. Proceedings of the National Academy of Sciences of the United States of America, 101, 18228-18233 (2004). https://doi.org/10.1073/pnas.0405211101

Rosenberg, J.N., Mathias, A., Korth, K., Betenbaugh, M.J., Oyler, G.A. Microalgal biomass production and carbon dioxide sequestration from an integrated ethanol biorefinery in Iowa: A technical appraisal and economic feasibility evaluation. Biomass and Bioenergy, 35, 3865-3876 (2011). https://doi. org/10.1016/j.biombioe.2011.05.014

Sawayama, S., Minowa, T., Yokoyama, S.Y. Possibility of renewable energy production and $\mathrm{CO}_{2}$ mitigation by thermochemical liquefaction of microalgae. Biomass and Bioenergy, 17, 33-39 (1999). https:// doi.org/10.1016/S0961-9534(99)00019-7
Schneider, S.H. The Greenhouse Effect: Science and Policy. Science, 243, 771-781 (1989). https://doi. org/10.1126/science.243.4892.771

Soares, F.R., Martins, G., Seo, E.S.M. An assessment of the economic aspects of $\mathrm{CO}_{2}$ sequestration in a route for biodiesel production from microalgae. Environmental Technology, 34, 1777-1781 (2013). https://doi.org/10.1080/09593330.2013.816784

Thomas, D.M., Mechery, J., Paulose, S.V. Carbon dioxide capture strategies from flue gas using microalgae: a review. Environmental Science and Pollution Research, 23, 16926-16940 (2016). https://doi.org/10.1007/s11356-016-7158-3

Watanabe, K., Fujii, K. Isolation of high-level- $\mathrm{CO}_{2}-$ preferring Picochlorum sp. strains and their biotechnological potential. Algal Research, 18, 135143 (2016). https://doi.org/10.1016/j.algal.2016.06.013

Yen, H.W., Ho, S.H., Chen, C.Y., Chang, J.S., $\mathrm{CO}_{2}$, $\mathrm{NO}_{\mathrm{x}}$ and $\mathrm{SO}_{\mathrm{x}}$ removal from flue gas via microalgae cultivation: A critical review. Biotechnology Journal, 10, 829-839 (2015). https://doi. org/10.1002/biot.201400707

Zhao, B., Su, Y. Process effect of microalgal-carbon dioxide fixation and biomass production: A review. Renewable and Sustainable Energy Reviews, 31, 121-132 (2014). https://doi.org/10.1016/j. rser.2013.11.054 
